\title{
KARAKTERISTIK DAN AKAR MASALAH KEMISKINAN Kasus Pada 4 Tipologi Desa di Kabupaten Sumbawa
}

\author{
Syaifuddin Iskandar ${ }^{1}$, Amir Mahmud ${ }^{1}$, dan Muslim ${ }^{1}$ \\ 1 Universitas Samawa, Sumbawa Besar, Nusa Tenggara Barat \\ Jalan Raya Sering, Unter Iwes Sumbawa, Nusa Tenggara Barat, Telp: (0371) 23543
}

Diterima 15 Desember 2009/ Disetujui 3 Mei 2010

\begin{abstract}
This research meant to dig and comprehends indicators distinguishing characteristic and poorness problem root in Sumbawa regency. Because of research region broadness, hence research subject is determined in purposive by four countrysides assessed representation able to in geographical typology complete and characteristic countryside public and also level of poorness of resident Sumbawa regency in general. As for fourth of countryside typology is rural area, mountain area, coastal area, and sub urban area. Analyzer applied to comprehend characteristic and poorness problem root of the countryside public, that is using analysis Method Participative Poorness, which developed with method Root Cause Analysis (RCA). This method applied to comprehend characteristic and poorness problem root in each countryside typology. The result of data analysis in general inferential that the poorness characteristic in each countryside typology actually not solely determined by region typology, because at most all countryside typologies there is poor resident amounts which relative still big. This condition altogether determined by economic indicators as factor that is very influences level of prosperity/ poorness of countryside public.
\end{abstract}

Keywords: poorness, countryside typology, method participative poorness, level of prosperity

Abstrak: Penelitian ini dimaksudkan untuk menggali dan memahami karakteristik yang membedakan indikator dan akar penyebab kemiskinan di Sumbawa. Mengingat luasnya daerah penelitian, maka subjek penelitian ditentukan oleh empat desa yang dinilai mampu mewakili tipologi geografi dengan baik, karakteristik masyarakat perdesaan, dan tingkat kemiskinan di Kabupaten Sumbawa pada umumnya. Adapun tipologi empat pedesaan tersebut yaitu daerah perdesaan, pegunungan, pesisir, dan wilayah pinggiran kota. Analisis yang digunakan untuk memahami karakteristik dan akar masalah kemiskinan masyarakat pedesaan yaitu Method Participative Poorness, yang dikembangkan dengan metode Root Cause Analysis (RCA). Metode ini diterapkan untuk memahami karakteristik dan akar penyebab kemiskinan di masing-masing tipologi desa. Hasil analisis data secara umum dapat disimpulkan bahwa karakteristik kemiskinan setiap tipologi perdesaan pada kenyataannya semata-mata tidak ditentukan oleh tipologi daerah, sebab hampir setiap tipologi desa jumlah orang miskin masih relatif besar. Kondisi ini sepenuhnya ditentukan oleh indikator ekonomi sebagai faktor yang sangat mempengaruhi tingkat kesejahteraan/kemiskinan masyarakat pedesaan.

Kata kunci: kemiskinan, tipologi desa, metode partisipatif kemiskinan, tingkat kesejahteraan

\section{PENDAHULUAN}

Kemiskinan menjadi perhatian utama pembangunan yang direncanakan pemerintah selama beberapa dekade. Bahkan bisa dikatakan bahwa muara besar dari perencanaan pembangunan hingga abad 21 ini masih berkutat pada pengentasan dan penanggulangan kemiskinan. Pascakrisis 1998 yang melanda Indonesia misalnya, yang paling menonjol adalah munculnya program pengentasan kemiskinan pada berba- 
gai sektor yang ditangani pemerintah. Misalnya, di sektor Kehutanan terdapat program Padat Karya Kehutanan, di sektor kesehatan bersinergi dengan Depnaker, Koperasi dan UKM terdapat Program Jaring Pengaman Sosial (JPS). Untuk program sarana dasar terdiri dari; P2KP, P3DT, PEMP, PM3K, PPK, IDT, dan terakhir program beras miskin (Raskin). Selain itu, ada juga program untuk pengembangan ekonomi produktif misalnya: P4K, UPPKS, P3EL, USP/ KSP, dan LKM. Di bidang pendidikan ada program; Biaya Operasional Sekolah (BOS), di bidang kesehatan ada WSLIC, JPS Kesehatan, program subsidi BBM, infrastruktur desa hingga subsidi di sektor perikanan dan kelautan. (Jumansyah dan Ahmad Zaini, 2006:5).

Melihat begitu banyak program yang dilaksanakan pemerintah untuk pengentasan dan penanggulangan kemiskinan, semestinya kita sudah bergerak melampau kondisi yang disebut miskin (secara absolut). Namun yang terjadi, kemiskinan tetap menjadi persoalan utama dan mendasar di negeri ini. Apakah ini berarti kita belum bergerak maju dari kondisi sebelumnya? Jawabannya bisa sangat panjang dan beragam, dan kemudian kita dapati benang merah bahwa kemiskinan merupakan kenyataan yang selalu ada dalam tradisi manusia. Dalam tradisi keilmuan, kemiskinan belum menjadi konsep yang legitimate karena begitu banyak ragam dan kriteria untuk menentukannya.

Di antara begitu banyak ragam konsep kemiskinan yang ingin diukur oleh para pakar, muncul pula suatu pendekatan baru sebagai jalan tengah, yaitu pendekatan dengan menggunakan metode Analisis Kemiskinan Partisipatif (AKP). Secara keilmuan, metode ini bisa jadi tidak digunakan sebagai salah satu tools untuk membangun teori yang bersifat umum, tetapi semata-mata untuk bisa membangun suatu konsep yang hanya bisa menjelaskan obyek/subyek itu sendiri. Sebagai instrumen yang digunakan untuk orientasi pengambilan kebijakan pembangunan, AKP tentu menjadi instrumen yang bisa dicoba untuk menganalisis kondisi faktual kemiskinan masyarakat. Paling tidak instrumen AKP bisa menghindarkan pela$\mathrm{ku}$ perencaan terjebak dalam kesalahan memahami kondisi dan akar masalah kemiskinan yang muncul di tengah masyarakat.
Untuk kasus Sumbawa, bisa kita bedah kondisi kemiskinannya. Menurut versi BPS, untuk Pra Keluarga Sejahtera (PraKS) berturutturut dari tahun 2004-2007 adalah, 17.784 (18,92 persen), 19.9225 (20,40 persen), 22.256 (22,17 persen), dan 22.510 (22,24 persen). (Progress Report Bupati Sumbawa Tahun 2008). Data yang berbeda akan didapatkan jika merujuk pada instansi atau dinas yang lain. Misalkan data BKBPP tentang persentase Pra KS Kabupaten Sumbawa tahun 2003 adalah sebesar 59,39 persen, kemudian tahun 2006 turun menjadi 48,8 persen, dan tahun 2007 turun lagi menjadi 47,75 persen. Selain dari sisi jumlah, trend dari dua data ini juga menunjukkan perbedaan, di mana data BPS memperlihatkan trend yang meningkat sedangkan menurut versi BKBPP kemiskinan meski jumlahnya relatif besar namun trend dari tahun ke tahun menunjukkan penurunan.

Berdasarkan data kuantitatif tentang kemiskinan tersebut, ternyata sampai sekarang justru masih menimbulkan kontaversi. Untuk lebih memantapkan pemahaman kita terhadap kemiskinan yang terjadi di Kabupaten Sumbawa, maka penelitian ini dilakukan dalam upaya menggali secara lebih mendalam tentang akar masalah kemiskinan yang terjadi di daerah pedesaan selama ini, bukan hanya dari sisi kuantitatif, akan tetapi penting juga dikaji secara kualitatif berdasarkan kondisi riel para pelaku hidup dari masyarakat desa itu sendiri. Berdasarkan latar belakang masalah di atas, dapat dirumuskan masalah sentral dan tujuan yang dikaji dalam penelitian ini yaitu tentang karakteristik dan akar masalah kemiskinan yang ada di masing-masing tipologi desa yang diteliti.

Untuk membahas masalah kemiskinan sebagai fokus penelitian ini, digunakan berbagai konsep/teori, antara lain dalam World Summit for Social Development, Kopenhagen (1995) dikemukakan bahwa, kemiskinan memiliki wujud yang majemuk, termasuk rendahnya pendapatan dan sumber daya produktif yang menjamin kehidupan berkesinambungan, kelaparan dan kekurangan gizi, rendahnya tingkat kesehatan, keterbatasan dan kurangnya akses kepada pendidikan dan layanan-layanan pokok lainnya, kondisi tidak wajar dan kematian akibat penya- 
kit yang terus meningkat, kehidupan bergelandangan dan tempat tinggal yang tidak memadai, lingkungan yang tidak aman, serta diskriminasi dan keterbelakangan sosial. Kemiskinan juga dicirikan oleh rendahnya tingkat partisipasi dalam proses pengambilan keputusan dan dalam kehidupan sipil, sosial dan budaya.

Pendekatan yang digunakan oleh Badan Pusat Statistik (BPS) dalam menentukan penduduk miskin adalah pendekatan basic needs, di mana kemiskinan diartikan sebagai ketidakmampuan dalam memenuhi kebutuhan dasar, baik untuk kebutuhan makanan maupun untuk kebutuhan non makanan. Indikator yang digunakan adalah Head Count Index (HCI) yaitu jumlah dan persentase penduduk miskin yang berada di bawah garis kemiskinan. Garis kemiskinan dihitung berdasarkan rata-rata pengeluaran untuk makanan dan non makanan. Standar untuk kebutuhan makanan dihitung dari besarnya rupiah yang dikeluarkan untuk kebutuhan makanan yang menghasilkan energi 2100 kalori per hari, sedangkan untuk kebutuhan non makanan adalah besarnya rupiah yang dikeluarkan untuk memenuhi kebutuhan minimum seperti untuk perumahan, penerangan, bahan bakar, pakaian, pendidikan, kesehatan, transportasi, barang-barang tahan lama dan barang jasa esensial lainnya.

Tinjauan lain menurut ilmu ekonomi, yang menjelaskan bahwa karakteristik kemiskinan absolut merupakan dampak dari perpaduan antara tingkat pendapatan per kapita yang rendah dengan distribusi yang sangat tidak merata. Michael P. Todaro menjelaskan karakteristik ekonomi masyarakat miskin, yaitu;

(1) kemiskinan di pedesaan sebagai generalisasi pertama yang terbilang paling sahih (valid) mengenai penduduk miskin, di mana mereka pada umumnya bertempat tinggal di daerah-daerah pedesaan dengan mata pencaharian pokok di bidang pertanian dan kegiatan-kegiatan lainnya yang erat kaitannya dengan sektor ekonomi tradisional tersebut,

(2) kaum wanita, sebagai generalisasi penting kedua, di mana kemiskinan lebih banyak diderita oleh kaum wanita. Wanita adalah kelompok yang paling sering menderita kekurangan gizi, paling sedikit menerima pelayanan kese- hatan, air bersih, sanitasi dan berbagai bentuk jasa sosial lainnya (Todaro, 2000: 200-201).

Ahli ekonomi lainnya, mengelompokkan ukuran kemiskinan menjadi dua, yaitu kemiskinan absolut dan kemiskinan relatif. Kemiskinan absolut, diartikan sebagai suatu keadaan di mana tingkat pendapatan dari seseorang tidak cukup untuk memenuhi kebutuhan pokoknya seperti sandang, pangan, permukiman, kesehatan, dan pendidikan. Ukuran ini terkait dengan batasan pada kebutuhan pokok atau kebutuhan minimum. Sayogyo (1977) menyatakan bahwa untuk daerah perkotaan kebutuhan minimal perkapita setara dengan $420 \mathrm{~kg}$ beras per tahunnya, dan untuk daerah perdesaan $320 \mathrm{~kg}$. Kemiskinan relatif berkaitan dengan distribusi pendapatan yang mengukur ketidakmerataan. Dalam kemiskinan relatif, seseorang yang telah mampu memenuhi kebuthan minimumnya belum tentu disebut tidak miskin, karena apabila dibandingkan dengan penduduk sekitarnya, bisa jadi ia memiliki pendatapatan yang lebih rendah.

Kemiskinan, khususnya kemiskinan di kota erat kaitannya dengan langkanya peluang kerja yang produktif. Penduduk, baik pendatang (urbanis) maupun penduduk kota yang baru masuk angkatan kerja, dengan kemampuan yang dimiliki menciptakan kesempatan kerja dengan memanfaatkan kehidupan kota. Jika dipandang dari sudut ekonomi, maka ada beberapa faktor penyebab kemiskinan yaitu:

(1) secara makro, kemiskinan muncul karena adanya ketidaksamaan pola kepemilikan sumberdaya yang menimbulkan distribusi yang timpang. Penduduk miskin memiliki sumberdaya terbatas dan kualitasnya rendah,

(2) kemiskinan muncul akibat perbedaan dalam kualitas sumberdaya manusia. Kualitas sumberdaya manusia yang rendah berarti produktivitasnya rendah, yang pada gilirannya upahnya juga rendah. Rendahnya kualitas sumberdaya manusia ini karena rendahnya tingkat pendidikan, nasib yang kurang beruntung, adanya diskriminasi, atau karena keturunan,

(3) kemiskinan muncul akibat perbedaan akses pemanfaatan dan sumberdaya dan modal,

(4) di daerah perkotaan, derasnya arus migran masuk juga memberi dampak terhadap semakin banyaknya penduduk dalam kategori mis- 
kin. Prilaku para migran dalam kehidupan kota yang sedemikian rupa, yakni pengeluaran yang serendah-rendahnya di daerah tujuan (kota) agar dapat menabung untuk dapat di bawa pulang ketika mereka mudik ke kampung halaman (daerah asal), dan

(5) terputusnya akses pengairan di sebagian lahan pertanian, berdampak pada perubahan perilaku petani. Apabila petani tidak dapat segera mengantisipasi perubahan tersebut, mereka akan kesulitan untuk melakukan aktivitas produktif di bidang pertanian. Optimalisasi lahan yang telah terputus akses pengairannya perlu segera dipolakan agar kemanfaatannya oleh petani dan masyarakat perkotaan dapat dirasakan.

\section{METODE PENELITIAN}

Penelitian ini termasuk jenis penelitian deskriptif kualitatif. Lokasi penelitian ditentukan secara purposive, yang difokuskan pada empat Desa yang memiliki tipologi berbeda-beda, yaitu tipologi daerah pesisir (Desa Teluk Santong), daerah pegunungan (Desa Batu Dulang), daerah persawahan (Desa Songkar), daerah sub urban (Desa Kalimango). Pemilihan empat tipologi tersebut disesuaikan dengan kondisi umum wilayah geografis yang ada di Kabupaten Sumbawa.

Data dikumpulkan dengan menggunakan metode observasi partisipatif (problem solving), pencatatan dokumen (sensus) dan indepth interview (wawancara). Metode analisis data menggunakan metode Analisis Kemiskinan Partisipasi (AKP), yaitu salah satu cara yang digunakan untuk lebih mendekatkan konsep kemiskinan sesuai dengan karakteristik wilayah di mana kemiskinan tersebut didefinisikan. Analisis AKP dikembangkan dengan metode Root Cause Analysis (RCA) yaitu untuk memahami akar masalah kemiskinan di masing-masing tipologi desa. Metode ini menjadi salah satu pendekatan alternatif untuk memperkaya pendekatan penelitian kualitatif dalam menjelaskan/ menjawab fenomena-fenomena sosial yang terjadi di masyarakat.

Adapun langkah-langkah yang ditempuh dalam proses pengumpulan dan analisis data dengan metode AKP yaitu: (1) Pemetaan wilayah; gambaran kondisi alam, komoditas utama, ketersediaan dan kondisi sumber daya, yang dipetakan dengan teknik pleno desa, (2) Klasifikasi kesejahteraan yang dilakukan melalui pleno desa untuk mengetahui ciri-ciri orang miskin, bobot, kriteria dan klasifikasi masyarakat, (3) Sensus pembobotan setiap RT yang dilakukan oleh masing-masing RT sehingga dari klasifikasi kesejahteraan yang telah ditentukan dapat diketahui kelompok yang termasuk dalam kriteria miskin dan sangat miskin, (4) Tabulasi bersama hasil sensus dengan menggunakan teknik tabulasi, bobot dan skoring peserta/utusan dari masing-masing dusun yang melakukan identifikasi tentang kriteria miskin dan kaya sesuai jumlah skor yang diperoleh. Klasifikasi masing-masing indikator tersebut kemudian ditentukan berdasarkan skala pengukuran 1-4 di mana skala 1=miskin sekali, skala 2=miskin, skala 3=sedang, dan skala 4=kaya. Pada kegiatan ini masyarakat melakukan verifikasi serta cross check hasil tabulasi sesuai dengan istilah lokal, fakta dan kondisi riel yang dialami.

\section{HASIL DAN PEMBAHASAN}

(1) Desa Teluk Santong (Tipologi Daerah Pesisir). Desa Teluk Santong adalah salah satu desa yang berada di kawasan ano siup atau kawasan sebelah timur Kabupaten Sumbawa. Secara administratif, Desa Teluk Santong berada dalam wilayah Kecamatan Plampang dengan luas wilayah 107,24 km. Sebagai Pusat Pemerintahan, Desa Teluk Santong membawahi tiga dusun yakni: Dusun Teluk Santong, Labu Jontal, dan Dusun Ai Boro. Secara geografis, dusun Labu Jontal dan Teluk Santong berada di pesisir pantai, sedangkan Ai Boro tergolong dusun persawahan dan sebagian besar masyarakat bekerja sebagai petani. Meskipun terdapat satu dusun yang tergolong dusun bertipe persawahan, tetapi di dalam struktur budaya tradisional Sumbawa, Desa Teluk Santong sendiri dikelompokkan ke dalam kelompok desa pabiring atau desa pesisir pantai, di mana mata pencaharian, budaya dan struktur sosial masyarakatnya menggambarkan budaya masyarakat 
pesisir pada umumnya.

Masyarakat yang mendiami Desa Teluk Santong terhimpun dalam 341 keluarga batih (rumah tangga), berpenduduk 2409 jiwa, yang terdiri dari: penduduk laki-laki berjumlah 1261 jiwa, sedangkan perempuan berjumlah 1148 jiwa (data primer diperoleh melalui sensus dusun). Pada umumnya penduduk Desa Teluk Santong adalah masyarakat yang heterogen, karena berasal dari berbagai desa dan suku seperti suku Bugis yang menempati posisi sebagai penduduk mayoritas, kemudian disusul oleh penduduk yang datang dari berbagai kecamatan yang ada di Kabupaten Sumbawa, seperti dari desa yang ada di Kecamatan Plampang sendiri, Kecamatan Empang, Sumbawa, Batulanteh, termasuk juga dari daerah di luar Nusa Tenggara Barat yang kemudian berbaur menjadi satu komunitas sebagai penduduk Desa Teluk Santong. Proses kedatangan penduduk, ada yang datang karena proses perkawinan dengan masyarakat setempat, ikut kerabat bahkan ada yang sengaja datang untuk berusaha dan menetap di Teluk Santong. Secara umum penduduk Desa Teluk Santong hidup dari hasil laut dan berprofesi sebagai nelayan, pertanian, peternakan, dan perdagangan.

Sebagai masyarakat pesisir, umumnya penduduk Desa Teluk Santong bermata pencaharian sebagai nelayan, petani sawah dan ternak, pedagang dan sebagian kecil dari penduduknya adalah pegawai negeri sipil. Dalam konteks masyarakat nelayan, mayoritas masyarakat Teluk Santong tergolong nelayan kecil dengan fasilitas penangkapan ikan seadanya (perahu kecil, jala dan alat pancing biasa), dan dengan model dan mekanisme penengkapan ikan yang masih sangat sederhana. Sejalan dengan ini, pengetahuan dan kemampuan yang dimiliki nelayan pun pada umumnya di kategorikan nelayan kecil dan tradisional: pengetahuan turun-temurun yang merupakan warisan para pendahulunya. Hanya sebagian kecil saja dari nelayan setempat yang menggunakan alat penangkapan ikan yang tergolong modern. Dengan fasilitas dan penangkapan ikan seadanya yang dimiliki oleh sebagian besar nelayan setempat, bisa dimaklumi bila hasil tangkapan yang didapat baik jenis ikan dan jumlahnya tergolong kecil. Karenanya, sangat beralasan bila hasil yang di dapat dari hasil melaut semata-mata hanya bisa mecukupi kebutuhan hidup rumah tangga sehari-hari.

Berdasarkan hasil klasifikasi tingkat kesejahteraan masyarakat Desa Teluk Santong diperoleh hasil bahwa ada 11 (sebelas) indikator yang mengklasifikasikan kondisi dan karakteristik masyarakatnya yaitu; pekerjaan, alat melaut, bentuk rumah, sawah, jumlah ternak besar, pendidikan orang tua, tempat $b a b$, tempat berobat, sumber air minum, dan terakhir penerangan. Dari indikator tersebut ditentukan bobot dan kriterianya dengan skala 1-4. Skala $1=$ kasi asi pupu (miskin sekali), skala $2=$ kasi asi (miskin), skala 3=setuju tuju (sedang) dan skala $4=$ sugi (kaya). Tabel 1 memberikan gambaran tentang kondisi dan karakteristik masyarakat Desa Teluk Santong.

Berdasarkan hasil AKP yang diolah dari data sensus per dusun, diperoleh gambaran tentang klasifikasi jumlah rumah tangga miskin di Desa Teluk Santong, seperti Tabel 2.

Tabel 2 menggambarkan bahwa dari 644 rumah tangga, jumlah rumah tangga miskin dan sangat miskin di Desa Teluk Santong tercatat sebanyak 341 rumah tangga (rumah tangga miskin sebanyak 268, dan rumah tangga miskin sekali berjumlah 73 rumah tangga) dengan komposisi 52,95 persen. Jika dilihat sebaran per dusun maka dari ketiga dusun yang ada di Desa teluk Santong, klasifikasi penduduk miskin paling besar bertempat tinggal di Dusun Labu jontal, sebanyak 97 rumah tangga atau 47,8 persen, rumah tangga miskin dan miskin sekali 107 rumah tangga: rumah tangga miskin 97 atau 47,8 persen, sedangkan yang tergolong miskin sekali sejumlah 10 rumah tangga atau 4,9 persen dari 203 rumah tangga yang ada di labu jontal. Sementara penduduk yang tergolong sangat miskin umumnya bertempat tinggal di Dusun Teluk Santong yang berjumlah 60 kepala keluarga atau 17,7 persen.

Untuk mengetahui akan masalah kemiskinan yang terjadi di desa Teluk Santong, selanjutnya dianalisis dengan menggunakan Analisis Kerentanan (Root Cause Analysis/RCA) dan hasilnya menunjukkan bahwa akar penyebab masalah kemiskinan muncul pada indikator ketiadaan akses terhadap alat penangkapan ikan serta banyaknya tengkulak yang menjerat ma- 


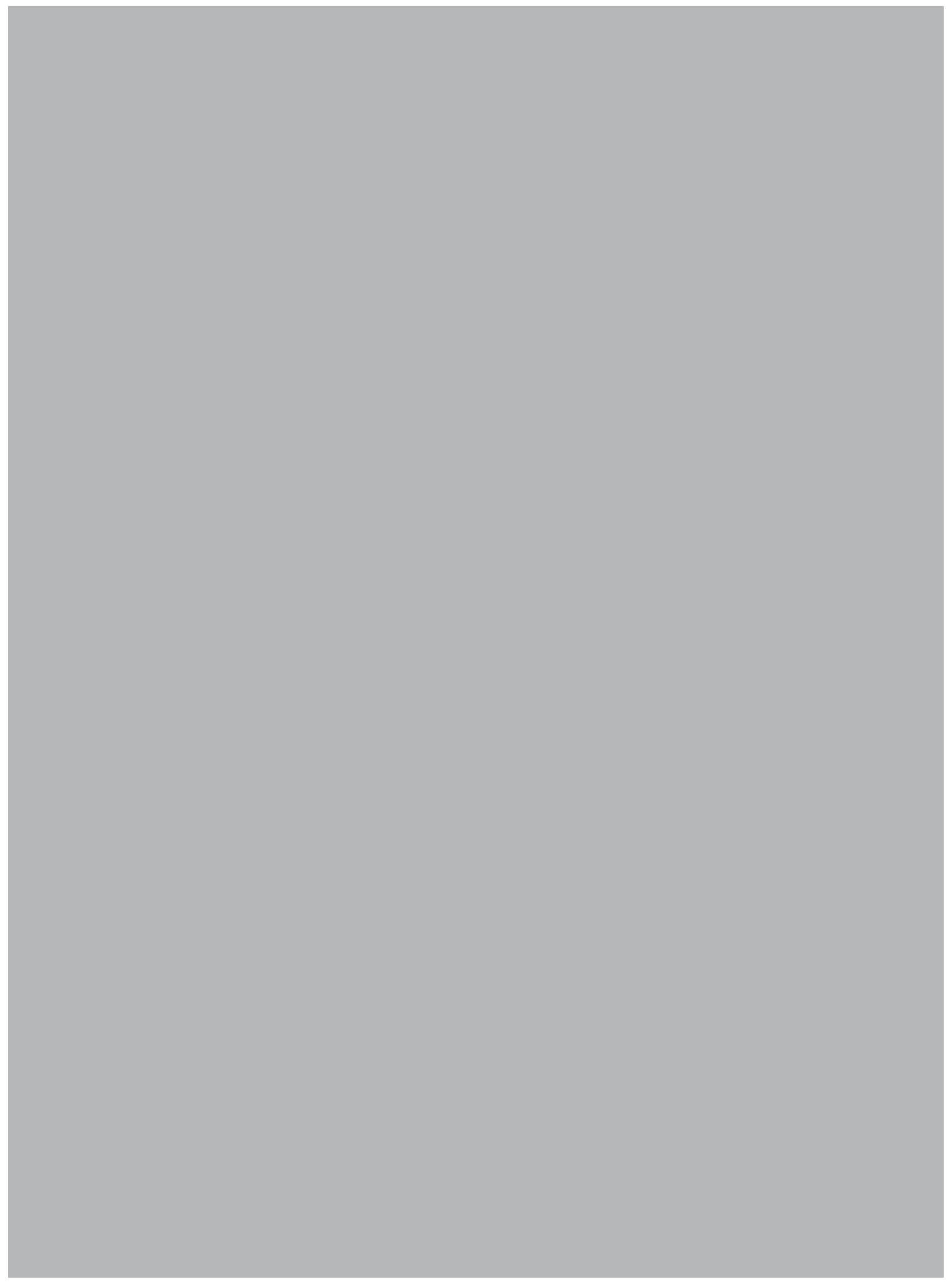


Sebagai ibukota desa, Desa Batu Dulang membawahi 2 dusun, yakni Dusun Batu Dulang dan Dusun Punik, dan membawahi dari 6 RT dan 4 RW. Sementara jarak tempuh kedua dusun tergolong dekat dan kurang lebih $10 \mathrm{~km}$, tetapi karena sulitnya transportasi jalan terutama pada musim-musim penghujan menyebabkan hubungan sosial masyarakat antar dusun (Punik dan Batu Dulang) sangat sulit dilakukan setiap saat. Secara geografis Desa Batu Dulang dan Kecamatan Batulanteh pada umumnya termasuk daerah dataran tinggi dan diklasifikasikan sebagai daerah pegunungan. Istilah lokal disebut Desa Bawo (terletak di dataran tinggipegunungan). Kondisi geografis yang sulit dijangkau, sarana penunjang transportasi seperti jalan yang buruk, juga penerangan listrik hanya ada di Desa Klungkung dan Dusun Batu Dulang.

Data Bappeda Sumbawa tahun 2007 menunjukkan bahwa semua desa yang ada di wilayah kecamatan Batulanteh masuk dalam kategori desa tertinggal tidak terkecuali desa Batu Dulang. Sebenarnya potensi alam Batulanteh sangat kaya raya: daerah penghasil kopi, kemiri, madu, dan berbagai jenis umbi-umbian yang lainnya. Potensi alam yang baik ini tidak ditunjang oleh sarana transportasi yang memadai itulah yang menjadikan daerah Batulanteh tergolong kecamatan miskin dan terisolir.

Dilihat dari klasifikasi pekerjaan penduduk, pada umumnya bekerja sebagai petani ladang sebanyak 154 kepala keluarga, sektor kehutanan sebanyak 71 kepala keluarga, PNS 7 kepala keluarga. Pertanian lahan kering sebagai pekerjaan utama penduduk dan komoditas yang dihasilkan berupa kopi, kemiri, dan sebagainya. Sedangkan bertanam padi dilakukan secara berladang dengan sistim gogorancah.

Berdasarkan hasil klasifikasi tingkat kesejahteraan masyarakat Desa Batu Dulang, diperoleh hasil bahwa 12 (duabelas) indikator yang mengklasifikasi kondisi dan karaktersitik masyarakatnya yaitu; kepemilikan kendaraan, pendidikan orang tua, pendidikan anak, alat memasak, tempat berobat, tempat $\mathrm{BAB}$, penerangan, bentuk rumah, ternak besar, pengeluaran per hari, pekerjaan dan luas kebun (tanah garapan). Dari indikator tersebut ditentukan bobot dan kriterianya dengan skala 1-4, dimana skala $1=$ kaperit (miskin sekali), skala $2=$ rara (miskin), skala $3=$ tepang (sedang), skala $4=$ sugi (kaya). Tabel 3 memberikan gambaran tentang kondisi dan karaktersitik masyarakat Desa Batu Dulang.

Secara keseluruhan Kecamatan Batulanteh tergolong kecamatan terisolir dan desa-desanya termasuk klasifikasi desa tertinggal, tetapi perkembangan ekonomi dan kesejahteraan penduduk Desa Batu Dulang cukup menggembirakan bila dibandingkan dengan dengan Desa Teluk Santong (representasi daerah pesisir). Perkembangan ekonomi dan tingkat kesejahteraan penduduk berdasarkan hasil sensus yang merujuk pada hasil pleno desa tentang kriteria, ciri dan karakteristik lokal klasifikasi kesejahteraan masyarakat, menjelaskan bahwa pada umumnya rumah tangga Desa Batu Dulang berada pada posisi berkecukupan (tidak kaya/tidak miskin) seperti tampak pada Tabel 4.

Tabel 4 menunjukkan bahwa dari 232 rumah tangga di Desa Batu Dulang, tercatat jumlah rumah tangga miskin dan sangat miskin adalah 45 rumah tangga dengan komposisi, 1,71 persen rumah tangga sangat miskin dan 17,67 persen rumah tangga miskin. Klasifikasi terbesar adalah rumah tangga tepang/sedang yakni 171 rumah tangga atau 73,71 persen. Rumah tangga yang termasuk klasifikasi kaya ternyata jauh lebih besar dari rumah tangga sangat miskin, yakni 16 rumah tangga atau 6,90 persen dari total populasi penduduk Desa Batu Batu Dulang yang mendiami dua dusun, yaitu Dusun Punik dan Dusun Batu Dulang. Jika ditelusuri dari data per dusun, maka dari total 45 rumah tangga miskin dan sangat miskin, 53,33 persen berada di Dusun Punik dan 46,67 persen berada di Dusun Batu Dulang.

Selanjutnya, untuk mengetahui akan masalah kemiskinan yang terjadi di desa Batu Dulang, dianalisis dengan menggunakan Analisis Kerentanan (Root Cause Analysis/RCA) dan hasilnya menunjukkan bahwa akar penyebab masalah kemiskinan muncul karena kurangnya akses terhadap transportasi yang relatif sulit serta menimbulkan biaya tinggi bagi masyarakat, terutama memukul petani perkebunan yang pendapatannya sudah minim, justru semakin memakan biaya tinggi terutama biaya 
sebelah timur Kecamatan Moyo Utara yang berbatasan dengan langsung dengan desa Berare di bagian selatan, di sebelah timur berbatasan dengan desa Batu Bangka, sebelah barat dan utara berbatasan dengan desa Pungkit.

Masyarakat Desa Songkar hidup dalam pemukiman yang berpola mengumpul (nugliated agriculture village comunity) rumah penduduk terkonsentrasi dalam satu lokasi, rumah yang satu dengan yang lainnya saling berdekatan dan umumnya masih kerabat dekat. Pemukiman penduduk dikelilingi oleh area persawahan atau yang lebih dikenal dengan sebutan "Orong Rea". Orong Rea semenjak zaman kesultanan Sumbawa menjadi "lumbung beras" bagi warga Sumbawa dan sekitarnya. Hal ini dimungkinkan karena adanya irigasi yang baik. Bagi sawah-sawah yang berlokasi di lokasi Orong Rea relatif tidak pernah mengalami gagal panen.

Luasnya hamparan pertanian terutama sawah, menjadikan sebagian besar masyarakat Songkar hidup sebagai petani. Dari 333 KK, 280 KK (1,025 orang) adalah keluarga petani, dan itupun tercatat $210 \mathrm{KK}$ petani dan memiliki lahan sawah di bawah $0,50 \mathrm{Ha}$, selebih nya 90 KK memiliki sawah di atas $1 \mathrm{Ha}$ dan rata-rata mereka memiliki ternak besar seperti kerbau dan sapi, dan masyarakat menyebutnya tau ada (orang kaya). Tau ada pada umumnya adalah mereka yang memiliki lahan pertanian terutama sawah di atas $1 \mathrm{Ha}$, memiliki ternak besar umumnya berasal dari para pegawai negeri sipil. Berdasarkan catatan desa, tercatat ada 33 kk (135 orang) yang tidak memiliki lahan pertanian dan hidup sebagai buruh tani dan buruh lepas. Masyarakat yang tidak memiliki lahan pertanian di sebut sebagai tau nonda atau orang miskin. Sebagian kecil dari masyarakat setempat atau sekitar 40 orang tercatat sebagai PNS dan pegawai swasta.

Bila dibandingkan dengan desa-desa lain di Kecamatan Moyo Utara, kondisi ekonomi dan tingkat kesejahteraan masyarakat Songkar cukup menggembirakan, dan mengalami perkembangan pesat dari waktu ke waktu. Perkembangan ini disebabkan oleh peningkatan hasil sektor pertanian (padi, kacang), terutama setelah berfungsinya Waduk Batu Bulan yang mampu mencukupi kebutuhan area persawah- an masyarakat Songkar hingga bisa panen sampai tiga kali setahun. Selain pertanian, peternakan (sapi, kerbau) juga menjadi andalah penduduk Desa ini.

Berdasarkan hasil klasifikasi tingkat kesejahteraan masyarakat Desa Songkar, diperoleh hasil ada 13 indikator yang mengklasifikasi kondisi dan karakteristik masyarakatnya yaitu; indikator jumlah kali makan dalam sehari, penerangan, alat masak, pendidikan orang tua, pendidikan anak, sumber air minum, tempat berobat, tempat $\mathrm{BAB}$, bentuk rumah, pengeluaran per bulan, pekerjaan, jumlah ternak besar, dan sawah. Untuk membuat klasifikasi masing-masing indikator tersebut kemudian ditentukan skala pengukuran, yaitu: skala 1-4 dimana skala $1=$ kaperit (miskin sekali), skala $2=$ rara (miskin), skala $3=$ tepang (sedang), dan skala $4=$ sugi (kaya). Tabel 5 memberikan gambaran tentang kondisi dan karakteristik masyarakat Desa Songkar.

Berdasarkan hasil AKP yang diolah dari data sensus per dusun, diperoleh gambaran tentang klasifikasi jumlah rumah tangga miskin di Desa Songkar, seperti pada Tabel 6 .

Tabel 6 menunjukkan bahwa jumlah penduduk miskin dan sangat miskin di Desa Songkar tercatat 94 rumah tangga, dengan komposisi 24,2 persen termasuk dalam rumah tangga rara (miskin) dan 3,60 persen termasuk dalam rumah tangga kaperit (miskin sekali). Jumlah rumah tangga yang tercatat dengan klasifikasi tepang (sedang) adalah 221 rumah tangga atau 66,37 persen dari total penduduk Desa Songkar. Kemudian yang termasuk dalam klasifikasi sugi (kaya) tercatat 18 rumah tangga atau 5,41 persen dari total penduduk. Jika ditelusuri dengan data per dusun maka komposisi penduduk miskin dan termiskin dari tiga dusun yang ada di Desa Songkar, terbesar adalah Dusun Songkar B yaitu 45,74 persen dari total penduduk miskin, kemudian disusul Dusun Songkar A sebesar 34,02 persen dan terakhir Dusun Songkar Tengah sebesar 20,21 persen.

Selanjutnya, untuk mengetahui akan masalah kemiskinan yang terjadi di desa Songkar, dianalisis dengan menggunakan Analisis Kerentanan (Root Cause Analysis/RCA) dan hasilnya menunjukkan bahwa akar penyebab masalah kemiskinan muncul karena tidak bekerjanya 
diri dari tiga dusun yakni dusun Kerato, dusun Pok dan dusun Kalimango. Secara keseluruhan jumlah penduduk Kalimango berjumlah 3521 jiwa, yang terdiri laki-laki 1722 dan perempuan 1798. Secara keseluruhan penduduk tersebut terhimpun dalam 876 Kepala Keluarga.

Bila dilihat dari struktur penduduk, asal usul, agama, dan mata pencaharian penduduk masyarakat Kalimango sangat heterogen bila dibandingkan dengan desa-desa lainnya di Kabupaten Sumbawa. Penduduk yang saat ini bermukim di desa Kalimango berasal dari etnis Samawa (Sumbawa), Sasak, Jawa, Bima, dan Cina. Karenanya, selain bahasa Samawa (Sumbawa), bahasa Lombok/Sasak juga menjadi bahasa sehari bagi masyarakat sasak setempat. Begitu juga dengan keyakinan hidup (agama), tercatat 3454 penduduk beragama Islam, 12 orang beragama Kristen, 30 orang beragama Katolik dan 25 orang beragama Budha.
Berdasarkan hasil klasifikasi tingkat kesejahteraan masyarakat Desa Kalimango, diperoleh hasil ada 12 indikator yang mengklasifikasi kondisi dan karaktersitik masyarakatnya yaitu: penerangan, pendidikan anak, kendaraan, alat memasak, sumber air minum, tempat berobat, pengeluaran per hari, ternak, sawah basah, pendidikan orang tua, pekerjaan dan bentuk rumah. Ada empat skala untuk menentukan indikator miskin, yaitu skala $1=k a b o r a h$ (miskin sekali), skala 2=rara (miskin), skala $3=$ senang (sedang), dan skala 4 sugi=(kaya). Tabel 7 memberikan gambaran tentang karakteristik dan ciri-ciri masyarakat Desa Kalimango yang diidentifikasi berdasarkan hasil pleno.

Mata pencaharian hidup masyarakat Kalimango yakni petani sebanyak 255 rumah tangga (886 Orang), buruh tani 384 rumah tangga (1315 orang), buruh swasta (115 orang) pegawai

Tabel 7. Karakteristik Desa Kalimango (Tipologi Daerah Sub Urban)

\begin{tabular}{|c|c|c|c|c|}
\hline Karakteristik & $\begin{array}{l}\text { Sugi/Kaya } \\
(4)\end{array}$ & $\begin{array}{c}\text { Tepang/Sedang } \\
\text { (3) }\end{array}$ & $\begin{array}{c}\text { Rara/Miskin } \\
\text { (2) }\end{array}$ & $\begin{array}{c}\text { Kaperit/ } \\
\text { Miskin Sekali } \\
\text { (1) }\end{array}$ \\
\hline (12) Bentuk Rumah & Permanen & $\begin{array}{l}\text { Panggung/ } \\
\text { Semi Permanen }\end{array}$ & Rumah Gedek & $\begin{array}{l}\text { Tidak Punya } \\
\text { Rumah/ } \\
\text { Numpang }\end{array}$ \\
\hline (11) Pekerjaan & $\begin{array}{l}\text { Dagang/Toko/ } \\
\text { Pengusaha }\end{array}$ & $\begin{array}{l}\text { PNS/Tani/Kios/ } \\
\text { Bakulan }\end{array}$ & $\begin{array}{l}\text { Buruh Tani/Ada } \\
\text { tanah }\end{array}$ & Buruh \\
\hline $\begin{array}{c}\text { (10) Pendidikan } \\
\text { Orang Tua }\end{array}$ & Sarjana & SMA & SMP & SD \\
\hline (9) Sawah Basah & $>1-4 \mathrm{Ha}$ & $0,25-<1 \mathrm{Ha}$ & $>0,25 \mathrm{Ha}$ & - \\
\hline (8) Ternak & Besar & Sedang & Kecil & - \\
\hline $\begin{array}{l}\text { (7) Pengeluaran } \\
\text { Per hari }\end{array}$ & >30 Ribu & 11 Ribu - 30 Ribu & 7 Ribu - 10 Ribu & 6 Ribu \\
\hline (6) Tempat Berobat & Dokter/ & Rumah sakit/ Bidan & Puskesmas & Sanro/Dukun \\
\hline $\begin{array}{l}\text { (5) Sumber Air } \\
\text { Minum }\end{array}$ & Air Galon & PDAM & Sumur & $\begin{array}{l}\text { Ngaro/Minta } \\
\text { /Numpang }\end{array}$ \\
\hline (4) Alat memasak & Kompor Gas & Kompor minyak & $\begin{array}{l}\text { Kayu/ Minyak } \\
\text { Tanah }\end{array}$ & Kayu Bakar \\
\hline (3) Kendaraan & Roda 4 & Roda 2 & Sepeda & - \\
\hline $\begin{array}{l}\text { (2) Pendidikan } \\
\text { Anak }\end{array}$ & Sarjana & SMA & SMP & SD \\
\hline (1) Penerangan & $\begin{array}{l}\text { Listrik KWH } \\
900-1400\end{array}$ & Listrik KWH 450 & $\begin{array}{l}\text { Ngalir/Sambung } \\
\text { kabel tetangga }\end{array}$ & $\begin{array}{l}\text { Dila/Lampu } \\
\text { Templek }\end{array}$ \\
\hline
\end{tabular}

Sumber: Hasil Pleno Desa Tim AKP dengan penduduk Desa Kalimango 


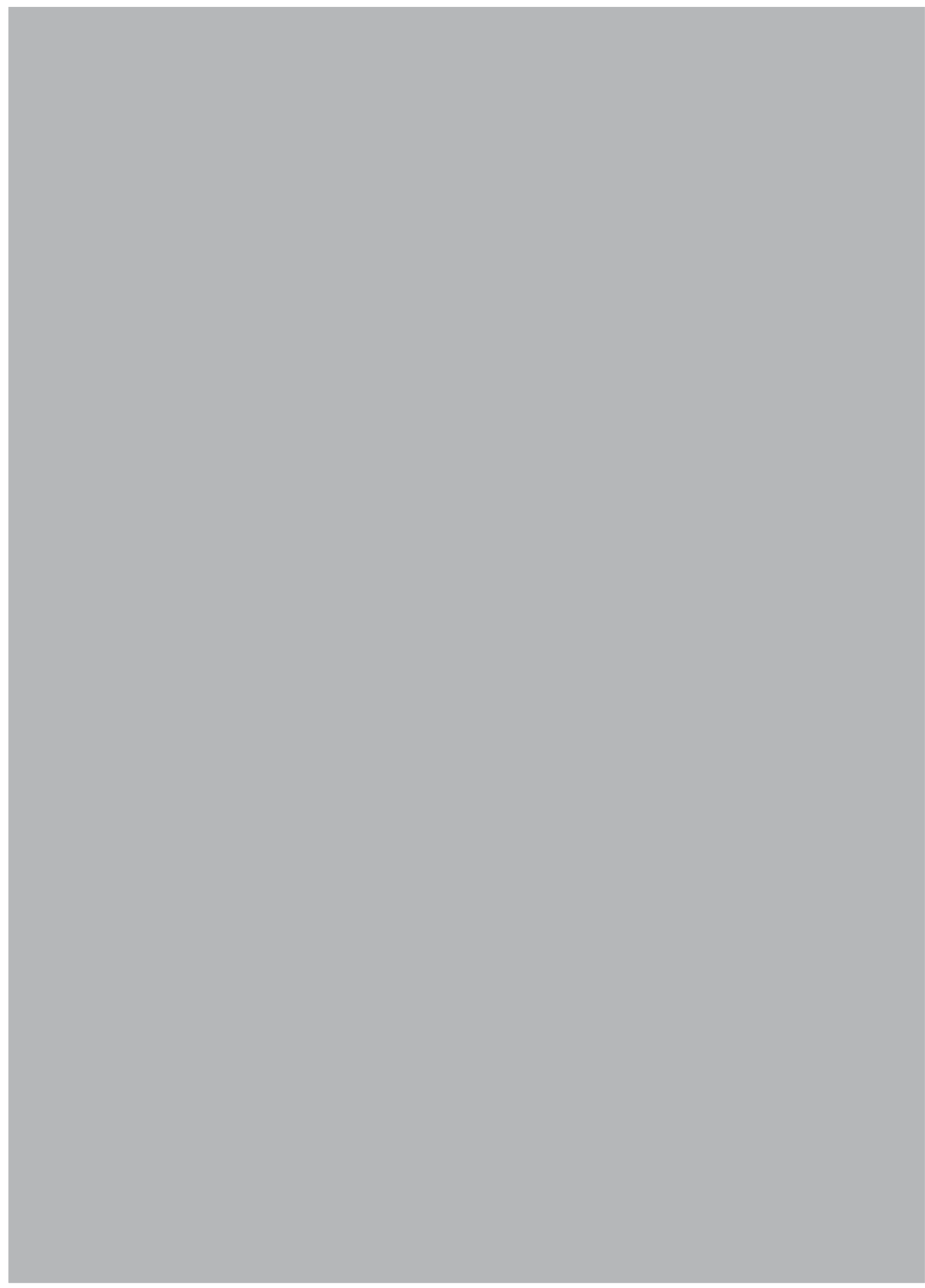


tor lokal dengan bobot masing-masing kriteria, diperoleh fakta bahwa pada kondisi dengan kriteria paling rendah adalah kondisi di bawah standar kenormalan bagi seseorang untuk hidup secara layak. Ini artinya, hasil AKP bisa dijadikan rujukan yang sangat kuat untuk mengukur dan menentukan siapa sebenarnya orang miskin tersebut.

\section{SIMPULAN}

Berdasarkan hasil analisis data dapat disimpulkan bahwa karakteristik kemiskinan yang ada di masing-masing tipologi desa sebenarnya tidak semata-mata ditentukan oleh tipologi wilayah, karena pada hampir semua tipologi desa terdapat jumlah penduduk miskin yang relative masih besar. Kondisi ini ditentukan oleh indikator ekonomi sebagai faktor yang paling menentukan tingkat kesejahteraan/ kemiskinan masyarakat desa, dan akar masalah kemiskinan masyarakat desa muncul karena hilangnya akses masyarakat terhadap sumberdaya ekonomi, yang terjadi karena proses marginalisasi, seperti kasus masyarakat suburban, karena lemahnya kapasitas masyarakat untuk mengoptimalkan potensi yang ada, seperti kasus desa persawahan dan pesisir dan juga karena aspek struktural sebagai dampak kebijakan, seperti kasus desa pegunungan.

Hasil penelitian ini diharapkan dapat dijadikan salah satu bahan dalam mengembangkan master plan kebijakan penanggulangan kemiskinan di Bapeda Kabupaten Sumbawa, serta menjadi referensi penting bagi pihak-pihak terkait yang ingin meneliti masalah kemiskinan.

\section{DAFTAR PUSTAKA}

Agusta, I. 2007. Aneka Metode Partisipasi untuk Pembangunan Desa. http://www.iagusta. blogspot.com/Sosiolog Pedesaan Institut Pertanian Bogor.

Aristo, D.A. 2004. Rejuvinasi Peran Perencana dalam Menghadapi Era Perencanaan Partisipatif". Disampaikan dalam Seminar Tahunan ASPI (Asosiasi Sekolah Perencana Indonesia) Malang: Universitas Brawijaya.

Bapeda Sumbawa, 2007. Progress Report Bupati Sumbawa. Sumbawa Besar: Kantor Bapeda Kabupaten Sumbawa.

Cahyono, B.Y. 2006. Metode Pendekatan Sosial dalam Pembangunan Partisipatif. www. lppm. petra.ac.id/ppm/COP/download.

Jumansyah dan Ahmad Zaini. 2006. Fasilitasi Kebutuhan Masyarakat Miskin, Sumbawa Besar: Samawa Center.

Todaro, Michael P. 2000. Pembangunan Ekonomi Dunia Ketiga. Alih Bahasa Aris Munandar Jakarta: Erlangga.

Muslim, Amir M. dan Amrullah. 2008. Peta Jalan Alokasi Anggaran Berbasis Pemenuhan Hak Dasar. Jakarta: Samawa Center dan Yayasan Tifa.

Saharia. 2003. Pemberdayaan Masayarakat di Pedesaan sebagai Salah Satu Upaya Pemanfaatan Potensi Sumberdaya Manusia Secara Optimal. Makalah Pengantar Falsafah Sains. Bogor: Sekolah Pascasarjana/S3 Institut Pertanian Bogor.

Soetomo. 2006. Strategi-Strategi Pembangunan Masyarakat, Yogyakarta: Pustaka Pelajar

Solihin, D. 2006. Perencanaan Pembangunan Partisipatif. Makalah disampaikan pada Pelatihan Aparatur Pemerintahan Daerah. Jakarta: Sekolah Tinggi Pemerintahan Abdi Negara.

Tampobulon, M. 2006. Pendidikan Pola Pemberdayaan Masyarakat dan Pemberdayaan Partisipasi Masyarakat dalam Pembangunan Sesuai Tuntutan Otonomi Daerah. Sumatera Utara: Fakultas Ilmu Pendidikan Universitas Negeri Medan. 